\author{
武田和宏 ${ }^{\dagger+} \cdot$ 柚木健一 ${ }^{*} \cdot$ 柘植義文・松山久義
}

\begin{abstract}
九州大学工学部 化学機械工学科, 812-8581 福岡市東区箱崎 6-10-1
生産技術の未成熟な工場において, 装置補修, 装置故障, 不良品, 割り込み受注は予め決められたスケ ジュールに従って生産することを阻害し, 生産性の低下, リードタイムの延長の原因となっている.

ここでは, 適正な予防的補修を行えば故障や不良品の発生を抑えることができると考えて, 装置補修を 頻繁に行っても高い生産性, 短いリードタイムを保持することができる分散型スケジューリングアルゴリ ズムを提案する。 さらに, 特定用途向集積回路製造工場の実データから作成したプラントモデルを用いて シミュレーションを行い, 光の有効性を確かめた。
\end{abstract}

緒言

工場の生産管理の最下層における意思決定は，(1) 工場へ投入 するロットの選択，(2) 投入時刻の選択，(3) 各装置で処理する口 ットの選択，（4）各装置における処理開始時刻の選択の 4 つの要 素によって構成される。一定期間の受注が確定したとき，その期 間内における 4 要素を予㛍決定したものをスケジュールと呼び, これに基づいて生産が実行される.

スケジュールに従った生産を阻害する要因は，(a) 装置の補修, （b）装置の故障, (c) 不良品, (d) 割り込み受注の発生である. 生 産技術が成熟していて, 阻害要因の発生頻度が小さい工場では, 予発生頻度の実績値に基づいた余裕のあるスケジュールを作成 することで対応できる.しかし, 製品・製法の陳腐化が早く, 生 産技術が未成熟である工場では, 装置の補修を頻繁に行っても, 装置の故障・不良品の発生を防ぐことが難しい。このような工場 において余裕のあるスケジュールを採用することは, 生産性を低 下させ，ロットを投入してから完成するまでの時間（リード夕イ ム）を長くする要因になっている.

製品・製法の陳腐化が早く，生産技術が未成熟である工場の代 表は, 特定用途向集積回路 (ASIC) 製造工場である. ASIC 製造工 場では複数の銘柄が 300 ステップ近い工程を経て生産されるが, 装置数はステップ数よりかなり少ない.すなわち, 同一の銘柄が 同一の装置を何度も通過して生産される. 工場の生産性は, 処理 速度の最も遅い装置（以下では律速装置と呼ぶ）の稼働率に支配 されるので, 過去の研究は, 律速装置の稼働率を $100 \%$ に近づけ るための処理ロットの選択法の開発に重点が置かれてきた.

Dayhoff ら (Dayhoff and Atherton, 1987)は, 律速装置の処理 ロットの選択を Earlier-step-first（受け持つ処理ステップの中で より上流の処理ステップを優先する), Later-step-first(より下流 の処理ステップを優先する), Round-robin(優先権を順番に与え る）の 3 方式について検討し Later-step-firstが最も好いという 結果を得ている，律速装置の稼働率をあげるには Earlier-stepfirstが好いはずであるが，これを採用すると律速装置の待ち行列 にロットが停滞するおそれがあるからである。

\footnotetext{
† 1997 年 6 月 16 日受理

化学工学会第 29 回秋季大会（京田辺，1996 年 9 月 17 日）にて発表

†† takeda@chem-eng.kyushu-u.ac.jp

* 山武八ネウェル株式会社
}

Lozinski ら (Lozinski and Glassey, 1988)は Bottleneck Starvation（BS）インディケー夕を用いて, 律速装置で処理すべき口 ットがなくなる状態（以下では, 物待ちと呼ぶ）が発生しないよ うに各装置の処理ロットを決定する方法を提案した。これは，律 速装置の稼働率を向上させるが, 後述するように, リード夕イム を長くするという欠点がある，また，両者の研究とも，阻害要因 については，実績值に基づいた余裕を見込むことしか考えていな い.

本研究では, 適切な予防的補修を行えば故障や不良品の発生を 抑えることができるという仮定の元に阻害要因の中の装置補修に 着目した。 また, 割り込み受注については無視した。装置補修が 生産性とリードタイムに及ぼす影響をできるだけ小さくするよう に，(1）投入ロット，(2）投入時刻を工場の入口で，(3) 処理ロッ 卜，(4) 処理開始時刻を各装置で分散して決定する方法(以下では Balance 法と呼ぶ）を提案する．また，ASIC 製造工場に関するシ ミュレーションにより, Balance 法と装置に到着した順序で処理 する方法 (FIFO 法) および LozinskiらのBS インディケータ (Lozinski and Glassey, 1988)を用いる方法（BS 法）と比較して, Balance 法の有効性を確かめる.

\section{1. 製造プロセス}

\section{1 律速装置の決定}

装置の加工能力を比較するとき，同時に複数の製品を製造する こと, 装置の故障・補修による停止時間などを考慮しなければな らないことから，単純にその装置が担当する処理での処理時間で 比較することはできない。工場の操業時間は, 装置が稼働してい る時間, 装置の故障・補修のために停止している時間, 装置は動 作可能だが原料がないために待つ時間の 3 種類に分類される. そ こで, 装置 $e$ に対して, 実際に動作可能な時間割合 $u(e)$ を $\mathrm{E}$. (1) で定義する.

$$
u(e)=\frac{T A-T S(e)}{T A}
$$

$T A$ : 工場の操業時間

$T S(e)$ : 装置の故障・補修による装置 $e$ の合計停止時間 故障の発生時刻, 修縜期間は未知であるが, それまでの長期操 業デー夕により平均的な故障発生率, 修繥期間は既知である。ま た, 補修の開始時刻, 補修期間は既知である. したがって, TS $(e)$ は過去の長期操業データに基づいた平均值として与えられる.

つぎに，それぞれの銘柄において装置 $e$ で担当するすべての処 


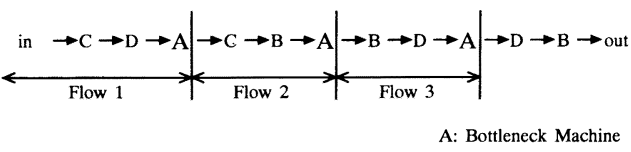

Fig. 1 Process flow and flow

理の 1 ロット当たりの処理時間の合計に銘柄の製造割合をかけた ものを合計稼㗢時間 $T W(e)$ とするとき, 装置 $e$ の加工能力を比 較するための代表処理時間 $\theta(e)$ を Eq. (2) で定義する.

$$
\theta(e)=\frac{T W(e)}{u(e)}
$$

$\theta(e)$ のきい装置ほど加工能力が小さいことを意味する.した がって, $\theta(e)$ が最も大きい装置が律速装置である.

\subsection{ASIC 製造プロセス}

ひとつのウェハ上には複数の ASIC が組まれており,さらに, U とつのロットという単位で複数のウェハが運ばれる，各装置は 1 ロットずつ処理する。この処理を処理ステップと呼ぶ。ウェハは 多くの装置を直列に経由して製品となる．銘柄毎に原料から製品 に至るまでの処理ステップの順列をプロセスフローと呼び, 律速 装置での処理ステップが最後になるようにプロセスフローを分割 した順列をフローと呼ぶ。ただし，プロセスフローの中で律速装 置による最後の処理ステップ以降はフローと呼ばない。亦る銘柄 bのプロセスフローおよびフローの概念困を Fig. 1 に示す．Fig. 1 において，A，B，CおよびDは装置を表し，A は律速装置を表 す。inからプロセスに入力されたロットはプロセスフローにした がって処理され，outから出力される.この間，ひとつの装置が複 数の処理ステップを担当する. プロセスフローは装置 A での処理 ステップごとにフローに分割される.

このような工場の加工能力は, 律速装置の加工能力に一致する はずであるが，実際の工場の加工能力は律速装置のそれを下回っ ている．この原因は，律速装置が物待ちを起こすことであると考 えられる。これに対して単純に物待ちをなくすために大量のロッ 卜を投入すると装置の待ち行列に処理待ちロットが蓄積する状態 (以下では物余りと呼ぶ)が発生する. 物待ち, 物余りは 1 ロット 当たりの製造期間を長くする。そこで，装置毎に分散して意思決 定して処理ステップ毎の処理ロット数を均一に保つことにより, 律速装置にできるかぎり物待ち, 物余りを起こさぬようにし，1口 ット当たりの製造期間を出来るだけ短くする必要がある.

\section{2. 既往のスケジューリング法}

本章では，最も単純な分散型スケジューリング法である FIFO 法抒よび既往の集中型スケジューリング法である BS 法を示す.

\subsection{FIFO 法}

各装置で処理が可能になったとき，処理すべきロットは待ち行 列の中から FIFOで選択し，すぐに処理を行う。工場へ投入する ロットは，注文の中から以下の指標 $\alpha$ を最小にする銘柄 $b$ とし， 律速装置の代表処理時間の間隔で1ロットずつ投入する。

$$
\alpha(b)=\frac{N A(b)}{p(b)}
$$

$N A(b)$ : 銘柄 $b$ の投入計画決定時刻までの投入口ット数 $p(b)$ : 銘柄 $b$ 製造割合

\subsection{BS 法}

LozinskiらのBS インディケータ (Lozinski and Glassey, 1988）を用いる方法である.

2.2 .1 プロセスロケーション 銘柄 $b$ の処理ステップ $s$ か
Table 1 Process location and cumulative inventory (a) Flow 1

\begin{tabular}{llrrr} 
& & $\rightarrow \mathrm{C}$ & $\rightarrow \mathrm{D}$ & $\rightarrow \mathrm{A}$ \\
\hline$w(b, i)$ & {$[\mathrm{min}]$} & 20 & 60 & 40 \\
$u(e)$ & {$[-]$} & 0.5 & 0.6 & 0.2 \\
$w(b, i) / u(e)$ & {$[\mathrm{min}]$} & 40 & 100 & 200 \\
\hline$d(b, s)$ & {$[\mathrm{min}]$} & 300 & 260 & 160 \\
\hline \hline$n(b, s)$ & {$[\mathrm{lot}]$} & 2 & 1 & 1 \\
\hdashline$f(b, j, d)$ & {$[\mathrm{min}]$} & 160 & 80 & 40 \\
\hline
\end{tabular}

(b) Flow 2

\begin{tabular}{llrrr} 
& & $\rightarrow \mathrm{C}$ & $\rightarrow \mathrm{B}$ & $\rightarrow \mathrm{A}$ \\
\hline$w(b, i)$ & {$[\mathrm{min}]$} & 25 & 100 & 10 \\
$u(e)$ & {$[-]$} & 0.5 & 0.5 & 0.2 \\
$w(b, i) / u(e)$ & {$[\mathrm{min}]$} & 50 & 200 & 50 \\
\hline$d(b, s)$ & {$[\mathrm{min}]$} & 290 & 240 & 40 \\
\hline \hline$n(b, s)$ & {$[$ lot $]$} & 1 & 1 & 5 \\
\hline$f(b, j, d)$ & {$[\mathrm{min}]$} & 70 & 60 & 50 \\
\hline
\end{tabular}

(c) Flow 3

\begin{tabular}{llrrr} 
& & $\rightarrow \mathrm{B}$ & $\rightarrow \mathrm{D}$ & $\rightarrow \mathrm{A}$ \\
\hline$w(b, i)$ & {$[\mathrm{min}]$} & 40 & 60 & 20 \\
$u(e)$ & {$[-]$} & 0.5 & 0.6 & 0.2 \\
$w(b, i) / u(e)$ & {$[\mathrm{min}]$} & 80 & 100 & 100 \\
$d(b, s)$ & {$[\mathrm{min}]$} & 260 & 180 & 80 \\
\hline \hline$n(b, s)$ & {$[1 \mathrm{ot}]$} & 0 & 1 & 4 \\
\hline$f(b, j, d)$ & {$[\mathrm{min}]$} & 100 & 100 & 80 \\
\hline
\end{tabular}

ら次に処理されるべき律速装置で処理開始可能になるまでの最小 時間をプロセスロケーション $d(b, s)$ と呼び, Eq. (4)で定義する.

$$
d(b, s)=\sum_{i=s}^{S(b, s)} \frac{w(b, i)}{u\{e(b, i)\}}-w\{b, S(b, s)\}
$$

$S(b, s):$ 銘柄 $b$ の処理ステップ $s$ を含むフロ一の律速装置で 行われる処理ステップ

$w(b, i):$ 銘柄 $b$ の処理ステップ $i$ での 1 ロットあたりの処理 時間

$e(b, i):$ 銘柄 $b$ の処理ステップ $i$ を行う装置

注意すべきことは，プロセスロケーションは各処理ステップか ら律速装置で処理開始可能となるまでの相対的な時間関係を表す ものであり，各処理ステップから律速装置で処理が開始されるま での絶対的な時間経過を表すものではないことである.

2.2 .2 累積作業量関数 銘柄 $b$ のフロー $j$ に含まれる処理 ステップの中で，そのプロセスロケーションが $d$ 以下となる最上 流の処理ステップからフローjの最後までの処理ステップの集合 を $D(b, j, d)$ とする. $D(b, j, d)$ に蓄積されているロットをフ ロ一の最後の装置（すなわち律速装置）が処理するのに要する時 間を銘柄 $b$ のフロー $j$ にける累積作業量関数 $f(b, j, d)$ と呼び, Eq. (5) で定義する.

$$
f(b, j, d)=W(b, j) \sum_{s \in D(b, j, d)} n(b, s)
$$

$W(b, j):$ 銘柄 $b$ のフローjにおける律速装置での処理時間 $n(b, s)$ : 銘柄 $b$ の処理ステップ $s$ に蓄積されているロット数 すなわち, $f(b, j, d)$ は銘柄 $b$ のフロー $j$ において現時刻から プロセスロケーション $d$ の時間内に律速装置での処理が実行可 能となったロットを律速装置で処理するときに必要となる作業量 （時間）を意味する。 


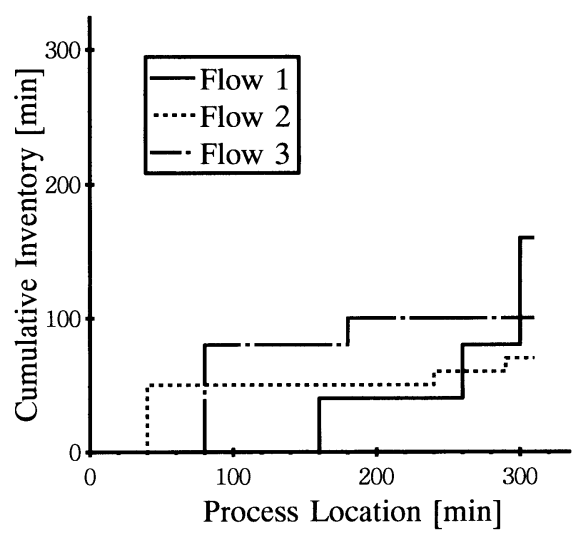

Fig. 2 Cumulative inventory

《例 1》Fig. 1 に示す銘柄 $b$ のプロセスフローのフロー1〜フロー 3 におけるプロセスロケーションと累積作業量関数の例を Table 1 に示寸. 第 1 行はそれぞれの処理ステップ i における処理時間 $w(b, i)$, 第 2 行は長期操業デー夕から計算した装置毎の実際に 動作可能な時間割合 $u(e)$ とする. 第 3 行は Eq. (4) 右辺第 1 項と なる各ステップ毎の（第 1 行)/(第 2 行) の計算值である. 第 4 行 はプロセスロケーション $d(b, s)$ である，例之ば，フロー 1 の装 置 A が担当する処理ステップの $d(b, s)=200-40=160[\mathrm{~min}]$ となり, 装置 D が担当する処理ステップの $d(b, s)=(100+$ 200) $-40=260[\mathrm{~min}]$ となる. 第 5 行はその処理ステップにある口 ット数 $n(b, s)$, 第 6 行は累積作業量関数 $f(b, j, d)$ である. 例 之ば, フロー 1 の装置 $\mathrm{A}$ が担当する处理ステップの $d(b, s)=$ 160 [min] であることから, $D(b, 1,160)$ は装置 A が担当する処 理ステップとなり，そこに 1 個のロットがあるので $f(b, 1,160)=$ $40 \times 1=40[\mathrm{~min}]$ となる. また, 装置 D が担当する処理ステップの $d(b, s)=260[\mathrm{~min}]$ であることから,$D(b, 1,260)$ は装置 D およ び装置 $\mathrm{A}$ が担当する処理ステップとなり, $f(b, 1,260)=40 \times$ $(1+1)=80[\mathrm{~min}]$ となる.これらの累積作業量関数を Fig. 2 に示 す. Fig. 2 では, 横軸がプロセスロケーション, 縦軸が累積作業量 関数である。(例終わり)

つぎに，すべての銘柄，管理対象であるすべてのフローにおけ る累積作業量関数の総和を工場全体の累積作業量関数 $F(d)$ と呼 び, Eq. (6)で定義する.

$$
F(d)=\sum_{b \in B} \sum_{j \in J} f(b, j, d)
$$

$B:$ すべての銘柄の集合

$J$ : 管理対象であるすべてのフローの集合

すなわち, $F(d)$ は, 工場全体で現時刻からプロセスロケーショ ン $d$ の時間内に律速装置での処理が実行可能となったロットを 律速装置で処理するときに必要となる作業量（時間）を意味する。 2.2 .3 BS インディケータ プロセスロケーション $d$ と工 場全体の累積作業量関数 $F(d)$ の関係を考えると, $d<F(d)$ の 場合は律速装置の処理能力よりも少ないロットが律速装置に到着 するため, 律速装置に物待ちが発生する可能性がある. $d>F(d)$ の場合は律速装置の処理能力を越えて多くのロットが律速装置に 到着するため, 律速装置に物余りが発生する可能性がある。そこ で，律速装置に物待ちも物余りも発生しないような理想的なロッ トの分布状態を表す関数を目標作業量関数 $T(t)$ と呼び， Eq. (7) で定義する。

$$
T(t)=t
$$

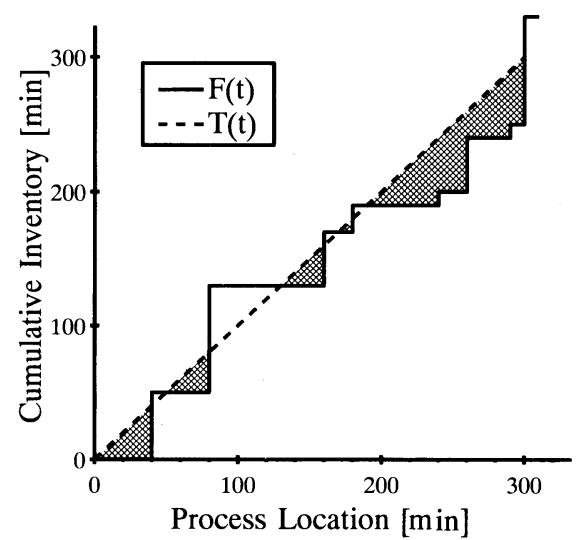

Fig. 3 BS indicator

Table 2 Changing of cumulative inventory

\begin{tabular}{llrrr} 
& & $\rightarrow \mathrm{C}$ & $\rightarrow \mathrm{D}$ & $\rightarrow \mathrm{A}$ \\
\hline$w(b, i)$ & {$[\mathrm{min}]$} & 20 & 60 & 40 \\
$u(e)$ & {$[-]$} & 0.5 & 0.6 & 0.2 \\
$w(b, i) / u(e)$ & {$[\mathrm{min}]$} & 40 & 100 & 200 \\
\cline { 1 - 1 }$(b, s)$ & {$[\mathrm{min}]$} & 300 & 260 & 160 \\
\hline \hline$n(b, s)$ & {$[\mathrm{lot}]$} & 1 & 2 & 1 \\
\hline$f(b, j, d)$ & {$[\mathrm{min}]$} & 160 & 120 & 40 \\
\hline
\end{tabular}

プロセスロケーション $t$ に対して, 工場全体の累積作業量関数 $F(t)$ と目標作業量関数 $T(t)$ の関係を示したグラフを BS イン ディケータと呼ぶ．Fig. 2 のフローのみを持つ工場における BS インディケー夕を Fig. 3 に示す. Fig.3において, 工場全体の累積 作業量関数 $F(t)$ は, Fig. 2 のフロー1〜フロー3を加え合わせた 階段状の実線で表し, 目標作業量関数 $T(t)$ を点線で表す。ここ で， $F(t) \leqq T(t)$ となる面積 (Fig. 3 の網掛け部分)を不足作業量 と呼ぶ．不足作業量は律速装置に将来物待ちが生じる可能性を意 味する. 装置 $e$ が処理可能になったとき, 待ち行列中に存在する 銘柄 $b$ の処理ステップsのロットを処理すると不足作業量が $L$ $(b, s)$ だけ減少する。各装置で処理が可能になったとき, 待ち行 列の中から以下の指標 $\beta$ が最も高いロットを選択し, すぐに処理 を行う。

$$
\beta(b, s)=\frac{L(b, s)}{w(b, s)}
$$

《例 2》例 1 の装置 C が処理可能となったとき, フロー 1 の装置 $\mathrm{C}$ での処理を行うと仮定すると, Table 1(a) は Table 2 のように変 化すると予測される。すなわち, 装置 $\mathrm{C} の n(b, s)$ が減り, 装置 $\mathrm{D} の n(b, s)$ が増加し, 装置 $\mathrm{D} の f(b, j, d)=40 \times(1+2)=$ $120[\mathrm{~min}]$ と予測される.よって, Fig. 2 の実線は Fig. 4 の 2 点鎤 線のように変化し, Fig. 3 の実線は Fig. 5 の 2 点鎖線のように変 化すると予測される。このとき，不足作業量は Fig. 5 の網掛け部 分の面積だけ減少すると予測される。この面積が $L(b, s)$ であ る. 同様に，フロー 2 の装置 Cでの処理を行うと仮定したときの $L(b, s)$ を計算し，不足作業量の減少速度のような意味を持つ指 標 $\beta$ の值が高いロットを選択する．ただし，予測したBS インデ イケー夕はあくまで次に行う処理を仮定した場合であり，実際の BS インディケー夕はいずれかのロットの処理が終了したときに 変更される．したがって，ここで選択した処理が終了する時点で は，他のいずれかの装置での処理が終了していれば予測した BS インディケータとは異なる。(例終わり)

2.2 .4 投入口ットの決定 注文の中から工場へ投入する口 


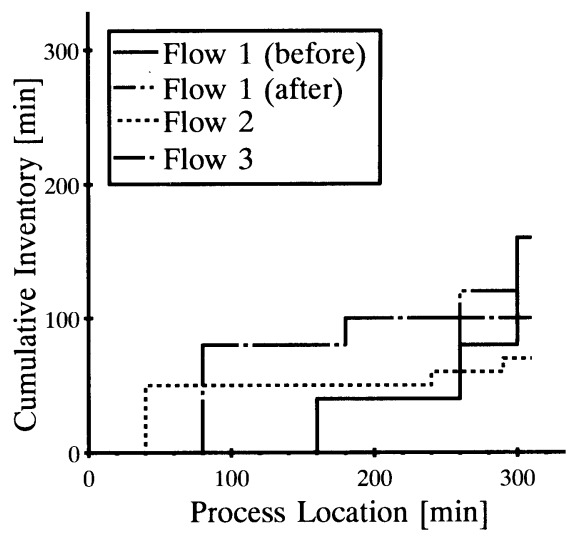

Fig. 4 Changing of cumulative inventory

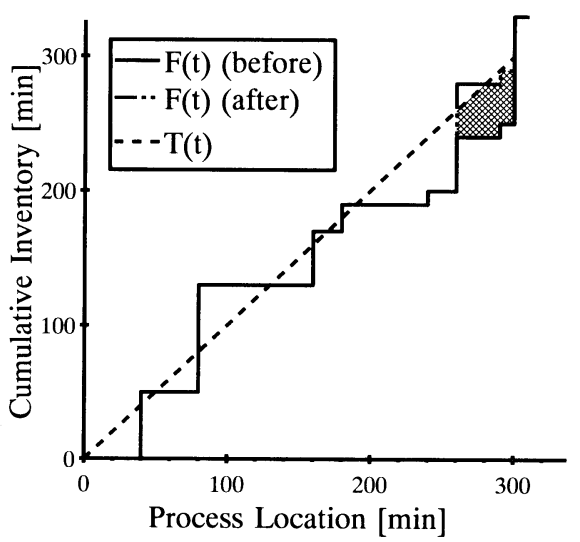

Fig. 5 Changing of BS indicator

ットの銘柄は FIFO 法と同じ指標を用いて決定し，律速装置の代 表処理時間の間隔でEq. (9)の条件を満たすか否か判定し, 満たし ていれば 1 ロット投入する. 満たしていなければ律速装置の代表 処理時間だけ後の時刻に再び Eq. (9)を判定する.

$$
\int_{0}^{d \max } F(t) d t<\int_{0}^{d \max } T(t) d t
$$

$d \max :$ 工場内のプロセスロケーションの最大值

$F(t)$ : 工場全体の累積作業量関数

$T(t)$ : 目標作業量関数

Eq. (9)を満たしたときは, 工場内のロットが少ないために, 律速 装置に物待ちが生じることを意味する。よって，これを防ぐよう にロットを投入する.

\section{3. 分散型スケジューリング法}

工場内の各装置が処理の進行状況に応じて自律的に処理ステッ プ前後の装置と協調し, 工場内に物待ちや物余りが生じるのを防 ぐ分散型スケジューリング法を提案する.

\section{1 処理開始可能時刻}

銘柄 $b$ の処理ステップ $s$ での処理において，あるロットを処理 した後に, 次のロットの処理を開始することのできる時刻を処理 開始可能時刻 $C(b, s)$ と呼び, Eq. (10) で定義する.

$C(b, s)=C^{\prime}(b, s+1)+\operatorname{MAX}_{i>s}[w(b, i)]-w(b, s) \quad(10)$

$C^{\prime}(b, s)$ : 銘柄 $b$ の処理ステップ $s$ の処理開始時刻 ただし，

$C(b, s)<C(b, s-1)$ のときは $C(b, s)=C(b, s-1)$

初期状態では $C(b, s)=0$

注意すべきことは, 処理開始可能時刻は「処理を開始することの できる時刻」であり「処理を開始しなければならない時刻」では

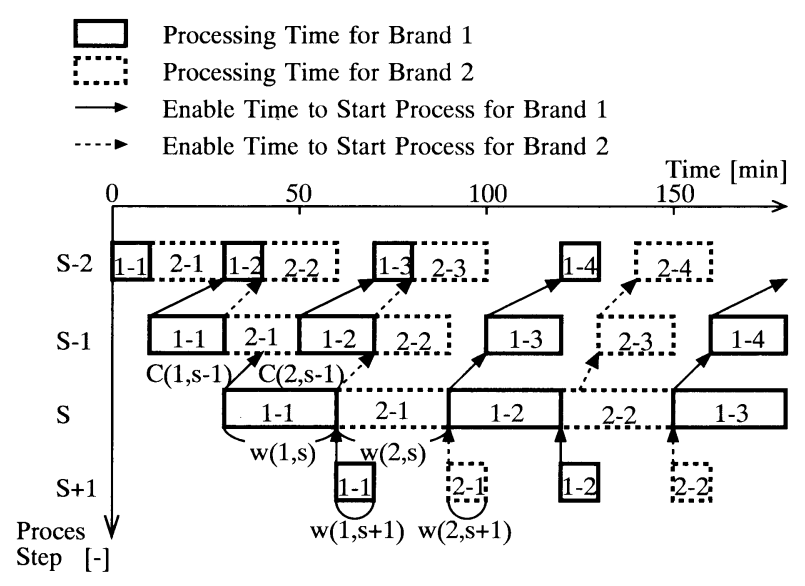

Fig. 6 Flow of lots and information

ないことである。すなわち, 処理開始可能時刻 $C(b, s)$ に満たな い時刻では銘柄 $b$ 処理ステップsのロットを処理してはならな いが, 必ずしも処理開始可能時刻 $C(b, s)$ に銘柄 $b$ 処理ステップ $s$ のロットを処理するわけではない.

《例 $3 》 2$ 銘柄を 4 装置 4 処理ステップで生産し, 故障・装置補修 が発生しない場合のロットおよび処理開始可能時刻の流れを Fig. 6 に示す. 横軸は時間, 縦軸は処理ステップ, 実線四角は銘柄 1 の処理時間, 点線四角は銘柄 2 の処理時間, 実線矢印は銘柄 1 の 処理開始可能時刻の伝達, 点線矢印は銘柄 2 の処理開始可能時刻 の伝達を表す．各銘柄は等量生産するものとする．初期状態とし ては, 待ち行列がないものとする。よって, 初期状態での各処理

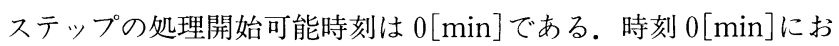
いて銘柄 1 のロット 1-1 を処理ステップ $\mathrm{S}-2$ で処理開始する.

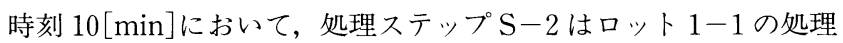
を終了し，直ちにロット $1-1$ を処理ステップ $\mathrm{S}-1$ に送り，銘柄 2 のロット 2-1を処理する. 処理ステップ $\mathrm{S}-1$ では銘柄 1 の処 理ステップ $\mathrm{S}-2$ に処理開始可能時刻を伝達し，ロット 1-1を処 理開始する。時刻 $40[\mathrm{~min}]$ において，処理ステップ $\mathrm{S}-2$ では口 ット1-2の処理を終了し, 直ちにロット $1-2$ を処理ステップ S-1に送り, 銘柄 2 のロット $2-2$ を処理開始する. 処理ステップ S-1 では銘柄 1 の処理開始可能時刻は過ぎているが，ロット21 を処理中であるため，ロット $1-2$ を処理することができず，時 刻 $50[\mathrm{~min}]$ になってようやくロット $1-2$ を処理開始する。（例終 わり)

一方，装置補修などにより装置が停止する場合，それに備えて バッファを蓄えておく必要がある. 銘柄 $b$ の処理ステップ $s$ を行 う装置 $e(b, s)$ の実際に動作可能な時間割合を $u\{e(b, s)\}$ とす る. $u\{e(b, s)\}$ が $u\{e(b, s+1)\}$ よりも小さいとき, それに反比 例して装置 $e(b, s)$ がロットを処理しておかなければ, 停止によ $\eta$ 装置 $e(b, s+1)$ は物待ちを起こすことになる.したがって, 銘 柄 $b$ 処理ステップ $s$ で処理した総ロット数を $N B(b, s)$ とする と，Eq. (11)を満足するまで，すなわち，動作可能な時間あたりの $N B(b, s)$ が一致するまで装置 $e(b, s)$ は処理開始可能時刻を過 ぎていなくとも処理を行う.

$$
u\{e(b, s)\} N B(b, s)=u\{e(b, s+1)\} N B(b, s+1)
$$

\section{2 ロット選択指標}

工場において，製造期間を短く，かつ，処理ロット数を多くす るためには，工場内を淀みなくロットが流れればよいはずである. そのためには, 各処理ステップにおいて処理したすべてのロット 数が均一になるように待ち行列を分布させればよいと考えられる。 
そこで，ある装置のすべての待ち行列において，処理開始可能時 刻をすぎたロットの中で，以下の指標 $\gamma$ が最小のロットを選択す る.

$$
\gamma(b, s)=\frac{N B(b, s)}{p(b)}
$$

ただし，初期状態において存在する仕掛かりロットは工場内の待 ち行列分布を乱していると考之，処理開始可能時刻を過ぎていな くとも選択対象とすることにより，できるだけ早く工場外一出力 させる.

\section{3 ロット投入指標}

注文の中から工場へ投入する処理ステップには無限個の待ち行 列が存在すると仮定する．装置補修などで製造が中断される場合, 製造期間が短い製品は製造再開と共に投入ロットを多くすること により，製造割合を満足することができる，一方，製造期間の長 い製品は停止分を見越して工場内に多く投入しておかなければ， 製造割合を満足することができない。そこで，投入する処理ステ ップを受け持つ装置で処理開始可能時刻をすぎた銘柄を $b$ とし たとき， $b$ よりも先の指標 $\gamma$ が小さく，かつ，以下の指標 $\varepsilon$ が大 きい銘柄があれば， $b$ は投入しない。そうでなければ， $b$ を 1 ロッ 卜投入する.

$$
\varepsilon(b)=p(b) T P(b)
$$

$T P(b)$ : 銘柄 $b$ の理論的な製造期間

本スケジューリング法における Eq. (12) および Eq. (13)の指標 は局所的な情報のみを利用するため，処理ステップの前後の装置 間でのみ交換した情報を元に意思決定することができる。すなわ ち，装置ごとに意思決定を分散し，Eq. (12)およびEq. (13)の指標 にしたがって装置が自律的に最適化することによって工場全体を 最適に導くことができる.

\section{4. シミュレーションによる比較検討}

\section{1 シミュレーション条件}

最も単純な分散型スケジューリング法である FIFO 法, 既往の 集中型スケジューリング法である BS 法，本研究で提案する分散 型スケジューリング法である Balance 法の 3 種類の方法で, ASIC 製造工場の運転の離散事象シミュレーションを行った。対 象とする工場は実工場を元にした架空の工場である，工場内の装 置数は 69 台である. 製造銘柄は 2 銘柄であり, シミュレーション 期間は 96 日間である。それぞれの銘柄のシミュレーション条件を Table 3 に示寸. Table 3 において第 2 行目は処理ステップ数, 第 3 行目は理論的な最小製造期間 (以下では単に理論値と呼ぶ) であ る.第 4 行目は注文の平均値であり,この平均值のポアソン分布に 従った時間間隔で各銘柄の注文が発生する。第 5 行目は注文の納 期であり，注文発生から 15 日間とした。第 6 行目は製造割合であ る.

工場の初期状態として仕掛ロットがない状態とある状態を想定 した. 仕掛かりロットは, FIFO 法により仕掛かりロットのない状 態から装置の補修を行いつつ上記の条件によりシミュレーション した最終状態から作成した。また，装置を適切に補修していれば, 装置故障や不良品は発生しないはずであることから，阻害要因と しては装置補修のみを取り扱った。装置補修は工場の操業デー夕 により，開始時間，補修時間ともに既知である。シミュレーショ ンには開始時間，補修時間ともに必要であるが，Balance 法によ るスケジューリングには回数と 1 回当たりの所要時間のみ必要で あり，開始時閒は不要である，以下では結果の整理のために，初
Table 3 Simulate condition

\begin{tabular}{lrr}
\multicolumn{1}{c}{ Brand } & \multicolumn{1}{c}{1} & \multicolumn{1}{c}{2} \\
\hline Process step [step] & 233 & 230 \\
Minimal production time [min] & 9,323 & 8,227 \\
Request period [day/lot] & 1.1 & 0.8 \\
Initial delevery date [day] & 15 & 15 \\
Production rate [-] & 0.413 & 0.587 \\
\hline
\end{tabular}

Table 4 Performance of Various Methods

\begin{tabular}{llccc}
\hline Cond. Method & $\begin{array}{c}\text { Processing } \\
\text { rate of } \\
\text { bottleneck } \\
\text { machine }[-]\end{array}$ & $\begin{array}{c}\text { Complete } \\
\text { lots } \\
{[\text { lot }]}\end{array}$ & $\begin{array}{c}\text { The rate } \\
\text { of ideal } \\
\text { and real } \\
\text { lead-time }[-]\end{array}$ \\
\hline $\mathrm{N}-\mathrm{N}$ & FIFO & 0.96 & 233 & 1.62 \\
& BS & 0.97 & 211 & 2.23 \\
& Balance & 0.97 & 238 & 1.58 \\
$\mathrm{~N}-\mathrm{E}$ & FIFO & 0.93 & 199 & 3.01 \\
& BS & 0.90 & 203 & 3.52 \\
& Balance & 0.91 & 221 & 2.65 \\
$\mathrm{E}-\mathrm{N}$ & FIFO & 1.00 & 272 & 3.07 \\
& BS & 0.97 & 268 & 3.40 \\
& Balance & 0.95 & 277 & 1.64 \\
$\mathrm{E}-\mathrm{E}$ & FIFO & 0.99 & 258 & 3.97 \\
& BS & 0.93 & 250 & 3.43 \\
& Balance & 0.90 & 261 & 2.72 \\
\hline
\end{tabular}

期状態で仕掛かりロットがない場合，かつ，装置補修を行わない 場合を場合 $\mathbf{N}-\mathbf{N}$ ，装置補修を行う場合を場合 $\mathbf{N}-\mathbf{E}$ と，初期状 態で仕掛かりロットがある場合，かつ，装置補修を行わない場合

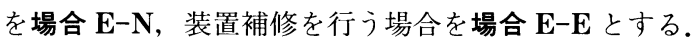

\section{2 結果および考察}

各条件における律速装置稼働率，完成ロット数，製造期間の理 論值との比を Table 4 に示す。第 1 列は初期状態と装置補修によ る場合分け, 第 2 列はスケジューリング法, 第 3 列は律速装置稼働 率, 第 4 列は完成ロット数, 第 5 列は製造期間の理論值との比を表

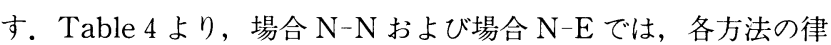
速装置稼働率はほぼ同じである。多くの製品を短い製造期間で製 造できるのは，場合 $\mathrm{N}-\mathrm{N}$ では Balance 法, FIFO 法, BS 法の順 であり，場合 N-Eでは Balance 法, BS 法, FIFO 法の順であ

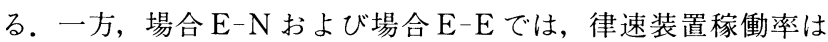
FIFO 法, BS 法, Balance 法の順に低くなるが，多くの製品を短 い製造期間で製造できるのは Balance 法, FIFO 法, BS 法の順で ある。これらのことから，初期状態で仕掛かりロットがない場合 には, FIFO 法を用いてもある程度の性能が得られる.ただし，運 用時には初期状態で必ず仕掛かりロットが存在すると考之られ， このとき, FIFO 法では性能が落ちる.これに対して, Balance 法 では，いずれの状態においても良好な性能を得られることがわか る.

つぎに，完成ロットの中で納期を満たすロット数を Fig. 7 に示 す. Figs. 7(a) (b)において，グラフ全体は完成ロット数，縦網掛 けは納期内に完成したロット，薄い網掛けは納期に遅れたロット を示す. Fig. 7(a) は場合 N-N, Fig. 7(b) は場合 N-Eの結果であ る. Fig. 7 (c) (d)において，グラフ全体は完成ロット数, 横網掛け は仕掛かりロット，縦網掛けは納期内に完成した投入口ット，薄 い網掛けは納期に遅れた投入ロットを示す。なお，仕掛かりロッ トはすべて納期内に完成した. Fig. 7 (c) は場合 E-N, Fig. 7 (d) は 場合 E-Eの結果である.

Fig. 7 (a)より，装置補修による停止が発生しなければ，いずれ 


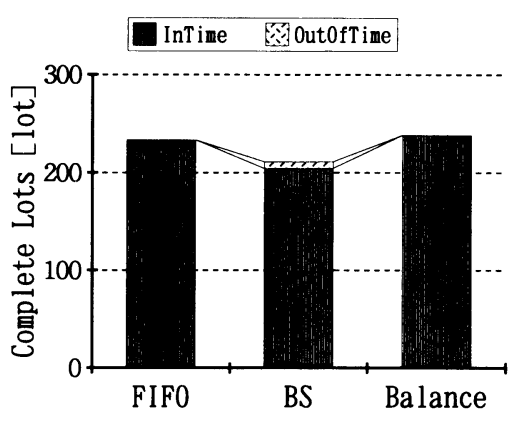

(a) Condition $\mathrm{N}-\mathrm{N}$

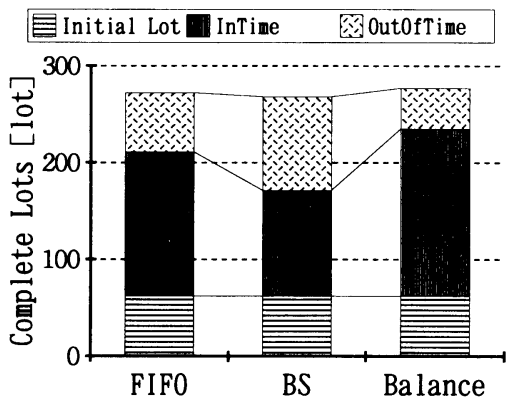

(c) Condition E-N

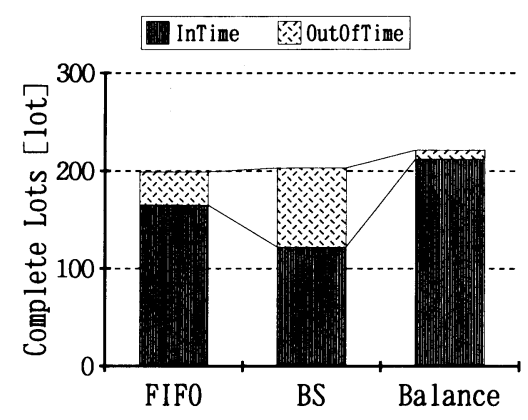

(b) Condition N-E

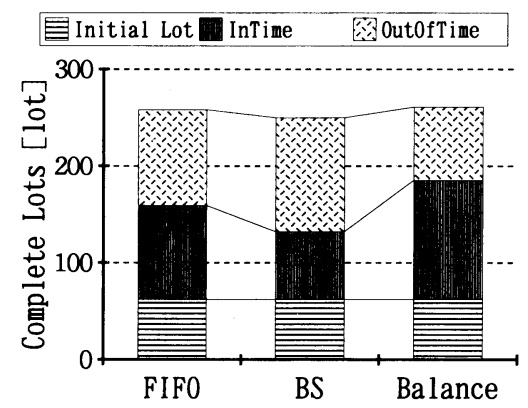

(d) Condition E-E

Fig. 7 Complete Lots for Various Methods

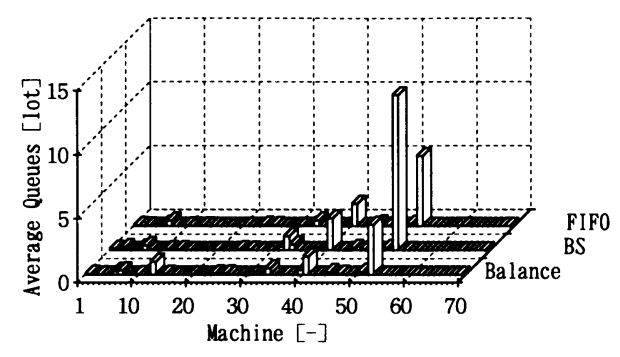

(a) Condition $\mathrm{N}-\mathrm{N}$

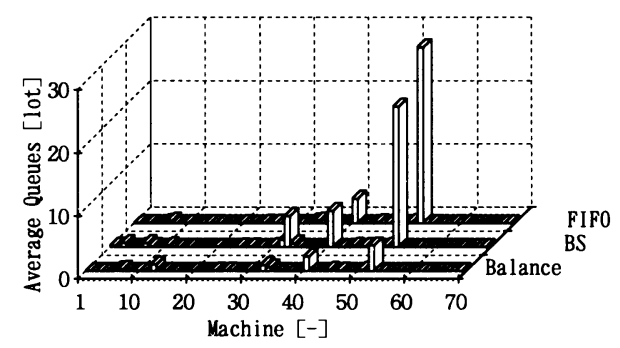

(c) Condition $\mathrm{E}-\mathrm{N}$

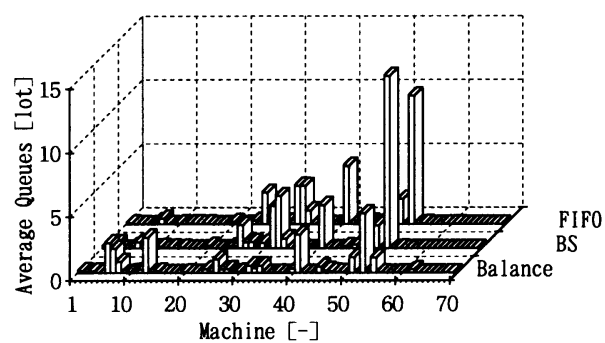

(b) Condition $\mathrm{N}-\mathrm{E}$

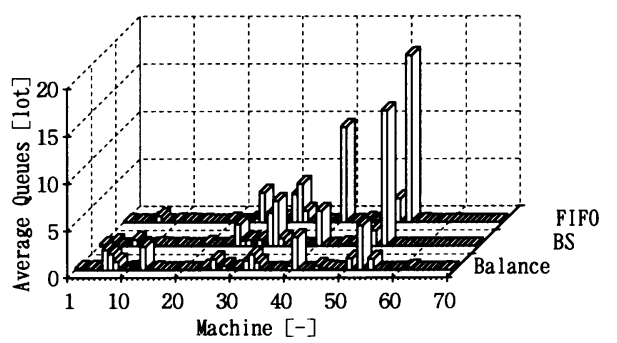

(d) Condition E-E

Fig. 8 Average queues per machine for various methods

の方法を用いても納期をほぼ満足する．Fig. 7(b)より，装置補修 による停止が発生すると, FIFO 法では完成ロットの $83 \%$, BS 法 ではわずか $60 \%$ が納期を満たすに過ぎない。これに対して，Balance 法では完成ロットの 96\% が納期を満たす. Fig. 7 (c)より, 仕 掛かりロットが存在してもほぼ同様の結論が得られる.Fig. 7(d) より, 仕掛かりロットがあり, かつ, 装置補修を行う場合には, Balance 法を用いても十分には納期を満たせない.よって, Balance 法はFIFO 法, BS 法より優れた方法であるが, 納期を考虑 する新たな対処が必要であると思われる。

FIFO 法, BS 法, Balance 法の性能差は, Fig. 8 に示寸工場内
の待ち行列分布に現れる. Fig. 8 において, 横軸は装置番号, 縦軸 は装置ごとの平均待ち行列数, 奥から順に FIFO 法, BS 法, Balance 法の結果である. Fig. 8より, 仕掛かりロットがあるか否 か, 装置補修を行うか否かに関わらず, FIFO 法および BS 法では 律速装置（装置番号 53）に待ち行列が集中するが, Balance 法で はより均等に待ち行列が分布する. Table 4 および Fig. 8 の結果 により, FIFO 法および BS 法では律速装置の物待ちは防ぐが物 余りが多く，それ以外の装置に過度の物待ちが生じたために，製 造期間が長くなり多くのロットが工場内に滞留する。滞留した口 ットはスムーズなロットの流れを阻害し, 完成ロット数が少なく 
なったものと考えられる。これに対して, Balance 法では, 律速 装置に多少の物待ちが発生するが, 全体として物待ち, 物余りが 適度に抑えられ，スムーズにロットが流れたものと考えられる。 すなわち，各処理ステップにおいて処理したロット数が均一にな るように待ち行列を操作することにより，多くの製品を短い製造 期間で製造することが可能であると考えられる.

以上のことから，本研究で提案するスケジューリング法である Balance 法は, 装置補修が頻繁に発生する場合でも納期内に多く の製品を製造することが可能な優れた方法であるといえる.

\section{結言}

Balance 法は，意思決定を工場の入口と各装置において分散し て行い，しかも，意思決定を行う場所の一つ下流の装置に関する 情報しか必要としないという特徵がある。これは, 数台の装置を 数人のグループで運転するという操業形態によく馴染む.

FIFO 法, BS 法と比較したとき, Balance 法は初期状態での仕 掛かりロットの影響をほとんど受けず，阻害要因の影響も一番小 さい。またほとんどの場合，多くのロットを短い製造期間で完成 させる優れた方法である。これは, Balance 法により各処理ステ ップにおいて処理したロット数を均一にすることが影響している と考えられる。

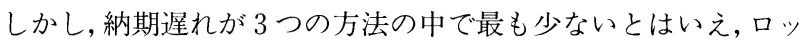
卜の初期分布と阻害要因によって増加する傾向がある点について は，今後の改良が必要である。

また，予防的に装置を補修することで装置の故障，不良品の発 生は防げるものと仮定して，阻害要因としては装置補修のみを取 り上げたが，現実には装置の故障・不良品の発生は防がれていな いし, 不良品の発生による不足分の追加投入, 試作品の投入など の割り込み受注も存在する.これらの阻害要因に対しても頑健な 方法の開発が期待される.

[謝辞]本研究は日本学術振興会未来開拓学術研究推進事業 JSPSRFTF 96 R 14301 の援助を受けた。ここに付記して感謝の意を表す.

\section{Nomenclature}

$b \quad$ brand

$B=$ set of all brands

$C(b, s)=$ enable time to start process in step $s$ for brand $b$

[min]
$C^{\prime}(b, s)=$ process start time in step $s$ for brand $b \quad[\mathrm{~min}]$ $d(b, s)=$ process location in step $s$ for brand $b \quad$ [min] $d \max =$ maximum process location in plant [min] $D(b, j, d)=$ set of process step which process location is under $d$ in flow $j$ for brand $b$ $e \quad=$ equipment $\quad[-]$ $f(b, j, d)=$ cumulative inventory function in flow $j$ for brand $b$

[min]

$F(d)=$ cumulative inventory function

[min]

$J \quad=$ set of all flows under management

$L(b, s)=$ reduction of insufficient inventory per a lot in step $s$ for brand $b \quad\left[\mathrm{~min}^{2}\right]$

$n(b, s)=$ number of lots in step $s$ for brand $b \quad[-]$

$N A(b)=$ number of throwed lots until decision time of throwing policy for brand $b \quad[-]$

$N B(b, s)=$ all processing lot count in step $s$ for brand $b \quad[-]$

$p(b)=$ production rate for brand $b \quad[-]$

$s \quad=$ process step $[-]$

$S(b, s)=$ process step by bottleneck machine in flow including process step $s$ for brand $b \quad[-]$

$t$ = time [min]

$T(t)=$ target inventory function $\quad[\mathrm{min}]$

$T A=$ operation time of plant [min]

$T P(b)=$ ideal production period for brand $b \quad[\mathrm{~min}]$

$T S(e)=$ total stopping time of equipment $e$ for failure or repair

TW $(e)=$ [min]

$u(e)=$ up time rate of equipment $e$ [-]

$w(b, s)=$ process time per a lot in step $s$ for brand $b \quad$ [min]

$W(b, j)=$ process time per a lot by bottleneck machine in flow $j$ for brand $b$

[min]

$\theta(e)=$ typical process time

$\alpha(b)=$ throwing indicator for FIFO method

$[\min ]$

$\beta(b, s)=$ selection indicator for BS method

$\gamma(b, s)=$ selection indicator for Balance method

$\varepsilon(b)=$ throwing indicator for Balance method

\section{Literature cited}

Dayhoff, J. E. and R. W. Atherton; "A Model for Wafer Fabrication Dynamics in Integrated Circuit Manufacturing," IEEE Trans. Syst. Man. Cyber, SMC-17, 91-100 (1987)

Lozinski, C. and C. R. Glassey ; "Bottleneck Starvation Indicators for Shop Floor Control,” IEEE Trans. Semi. Manu., 1, 147-153 (1988) 


\title{
Decentralized Scheduling Algorithm for Manufacturing Plants Reguiring Frequent Repairs
}

\author{
KAZUHIRO TAKEDA, KEN-ICHI YUNOKI*, YOSHIFUMI TSUGE \\ and HISAYOSHI MATSUYAMA
}

Department of Chemical Engineering, Kyushu University, Fukuoka 812-81

Key words: systems engineering, ASIC, robust scheduling algorithm, decentralized system.

Eguipment repair, eguipment failure, inferior goods, and urgent orders are major obstacles for scheduled production, and contribute to low productivity and long lead-time in manufacturing plants with incomplete production technology.

This paper presents a decentralized scheduling algorithm under the assumption that proper preventive repairs can decrease the occurrence of equipment failure and inferior goods. This algorithm can realize high productivity and short lead-time and be hardly affected by frequent equipment repair. The effectiveness of this algorithm is demonstrated by simulations of a plant model based on real plant manufacturing application specified integrated circuits.

* Yamatake Honeywell Co. Ltd. 